\title{
Inheritance of Resistance in Strawberry to Bacterial Angular Leafspot Disease Caused by Xanthomonas fragariae
}

\author{
K.S. Lewers, ${ }^{1}$ J.L. Maas, ${ }^{2}$ S.C. Hokanson, ${ }^{3}$ C. Gouin, ${ }^{4}$ and J.S. Hartung ${ }^{5}$ \\ Fruit Laboratory, Beltsville Agricultural Research Center, Agricultural Research Service, U.S. Department \\ of Agriculture, Beltsville, Maryland 20705
}

AdDITIONAL INDEX WORDs. Fragaria $\times$ ananassa, Fragaria virginiana, breeding

\begin{abstract}
AвStRact. Bacterial angular leafspot disease (Xanthomonas fragariae Kennedy and King) of strawberry (Fragaria species and $F$. $\times$ ananass $a$ Duch. cultivars) has become increasingly important to strawberry fruit and plant production. Strawberry cultivars and species vary in susceptibility to infection. However, little is known regarding epidemiology of the disease and resistance to infection. Two octoploid genotypes, a native $F$. virginiana (US 4808, tested as SG-89) and a $F$. virginiana (SG 26) $x F$. Xananassa ('Earliglow') hybrid (US 4809, tested as 80-4-38), previously were found to be highly resistant to two differentially pathogenic strains of $X$. fragariae representing two of four genotypic strain groups. Our objective was to determine the number of genes involved with resistance for these two strawberry genotypes, whether strawberry resistance is conferred by dominant or recessive alleles, and whether or not the heritability is high enough for breeders to reliably make selections of resistant individuals in breeding populations. About $120 \mathrm{~F}_{1}$ seedlings from crosses of susceptible 'Sweet Charlie' with each of the two resistant genotypes were clonally propagated and challenged with each of four $X$. fragariae strains. These strains were selected to represent four genotypes of $X$. fragariae defined by repetitive element based PCR: ATCC 33239, Xf3, Xf-6, and Xf-1425. Plants were quantitatively rated on a scale of 0 (resistant) to 5 (susceptible) in replicated evaluations. High estimates for broad sense heritability support the conversion of the quantitative disease scores to qualitative scores and the classification of genotypes as resistant or susceptible. The qualitative ratings were used to estimate the number of genes involved with resistance. Some segregation ratios fit a 7S:1R ratio, and others fit a 15S:1R ratio, indicating that three or four unlinked loci could explain the inheritance of resistance in these populations. The high estimates for broad sense heritability show that resistant progeny can be selected with confidence, though large populations will be needed to identify enough resistant progeny from which to select for other important traits.
\end{abstract}

Bacterial angular leafspot disease (BALD) of strawberry (Fragaria $\times$ ananassa Duch.), caused by the bacterium Xanthomonas fragariae Kennedy and King (1962a), was first documented from Minnesota in 1960 and now occurs in many strawberry growing areas of North America, Europe, South America, Africa, and Australasia. This disease affects only Fragaria species, and is most commonly transmitted by infected planting stocks. This disease can cause serious reductions in fruit yield and quality and plant losses in nursery production of transplants and has become a disease of international quarantine significance (Diekmann et al., 1994; Maas, 1998). Fruit yield losses due to BALD have ranged from $8 \%$ in a Florida annual production system (Roberts et al., 1997) to as much as $80 \%$ in a Wisconsin perennial production system (Epstein, 1966). Production of plug or container transplants also may be severely impacted through systemic infection by $X$. fragariae (Milholland et al., 1996; E.B. Poling, personal communication).

Management of BALD currently includes the use of clean transplants, management of moisture and nutrition, and applications of protective chemicals. Once BALD has become established in a planting, cupric hydroxide, and othercopper-containing compounds such as copper ammonium carbonate and mixtures with zinc iron, manganese ethylene bisdithiocarbamate (mancozeb) have been

Received for publication 2 July 2002. Accepted for publication 2 Dec. 2002. This work was funded in part by an USDA-ARS Germplasm Evaluation Grant. We wish to acknowledge the invaluable assistance of Kate Salazar, Sam Garrett, and Kathleen Haynes in the work reported here.

'Research plant geneticist and corresponding author; e-mail lewersk@ba.ars.usda.gov. ${ }^{2}$ Research plant pathologist; e-mail maasj@ba.ars.usda.gov.

${ }^{3}$ Assistant professor. Current address: Department of Horticultural Science, University of Minnesota, St. Paul, Minnesota; e-mail hokan017@umn.edu.

${ }^{4}$ Scientific research assistant; e-mail gouinc@ba.ars.usda.gov.

${ }^{5}$ Research plant pathologist; e-mail hartungj@ba.ars.usda.gov. shown to provide some protection against further spread of BALD (Averre and Driver, 1994; Roberts et al., 1997). Antibiotics, such as streptomycin sulfate, oxytetracycline also have been effectively used (Averre and Driver, 1994), although they are costly and not registered for use on strawberry. However, none of these materials act to eradicate existing Xanthomonas infections. In addition, multiple sprays at short intervals with copper may be phytotoxic (Roberts et al., 1997) and would likely lead to bacterial resistance to the compound (Cooksey, 1990).

Strawberry genotypes vary in relative susceptibility to infection by $X$. fragariae. 'Daybreak' reportedly was more severely affected by BALD than were 'Florida 90', 'Missionary', 'Tioga', 'Torrey', 'Salinas', and La. 1158, and infection of 'Florida 90' and 'Missionary' was minimal (Howard, 1971). Kennedy and King (1962b) found that of 64 cultivars and clones, only Minnesota 1716 (a third generation self of 'Belt' $x$ 'Premier') exhibited higher apparent resistance than the other genotypes in greenhouse inoculation tests. In other greenhouse tests, 'Badgerbelle' and 'Atlas' were found more resistant to infection than were 'Earliglow', 'Guardian', 'Sparkle', 'Stelemaster', 'Raritan', 'Midland', 'Fletcher', 'Surecrop', 'Blakemore', and 'Suwannee' (Hazel and Civerolo, 1980).

Inconsistencies in apparent disease reactions may be due in large part to differences in nutritional balances of plants, plant and leaf ages, genotype $\times$ environment interactions, and strains of $X$. fragariae involved (Kennedy and King, 1962a, 1962b; Maas et al., 2000). Pooler et al. (1996) recognized four groups of strains of X. fragariae based on enterobacterial repetitive intergenic consensus (ERIC) polymerase chain reaction (PCR), as well as other PCR based technologies. These strains were originally isolated at various locations around the world. These genetic differences in the pathogen population have not been considered in earlier studies on host reaction to infection by $X$. fragariae. Differential pathogenicities of 
$X$. fragariae strains to strawberry have only recently been documented. Maas et al. (2000) found that although plants of 'Lateglow', 'Mohawk', 'Winona', and California clone 61-16-99 appeared resistant to strain Xf-3, they were susceptible to strain ATCC 33239. To date, no commercial cultivars have been found to be resistant to infection by representatives of all four genotypic strain groups of $X$. fragariae.

Resistance to $X$. fragariae has been reported in some Fragaria species. Kennedy and King (1962a, 1962b) found that the diploid $F$. vesca L. ('Alpine') had low disease severity ratings compared to the others in greenhouse and field inoculation tests. Hazel (1981) found that of several Fragaria species evaluated by inoculation, only $F$. moschata Duch. (hexaploid) was immune and some $F$. virginiana Duch. (octoploid) clones displayed moderate degrees of tolerance. Based on the apparent widely dispersed origins of resistance in Fragaria spp. to $X$. fragariae, and the possible origin of $X$. fragariae in the western United States (Kennedy and King, 1962a; Linford, 1928; Maas et al., 1995), great potential exists for capturing genetic resistance to BALD utilizing native North American genotypes of $F$. virginiana or $F$. chiloensis.

The incorporation of resistance to $X$. fragariae from nonoctoploid species would involve complex manipulations and bridging crosses involving different ploidy levels (Bors and Sullivan 1997, 1998). Therefore, availability of resistant octoploid germplasm would provide an easier route for incorporating resistance into cultivated strawberry. In addition, such crosses also would serve to broaden the genetic base of commercial strawberry for disease resistance and resistance to biotic and abiotic stresses and could enhance plant and fruit traits as recommended by Luby et al.(1991) and Sjulin and Dale (1987). Thus, our objectives have been to identify octoploid germplasm sources for resistance to BALD.

Maas et al. (2000) reported that two genotypes, a native $F$. virginiana (US 4808, tested as SG-89) and an $F$. virginiana (SG-26) x F. ×ananassa ('Earliglow') hybrid (US 4809, tested as 80-4-38), were highly resistant to two differentially pathogenic strains of $X$. fragariae representing two of the four genotypic strain groups of $X$. fragariae reported by Pooler et al. (1996). In subsequent work, we found these two genotypes highly resistant to infection by representatives of all four genotypic strain groups (Maas et al., 2002). Both BALD resistant genotypes have been released to strawberry breeders (Maas et al., 2002). As far as we are aware, no previous studies have been made to determine the manner of inheritance of resistance to $X$. fragariae in strawberry. Our objective in the present work is to characterize the genetics of the disease-resistance reaction exhibited by strawberry genotypes US 4808 and US 4809.

\section{Materials and Methods}

Plants. Resistant $X$ susceptible genotype crosses were made for this study: clone US 4808 (SG-89) x 'Sweet Charlie' (seedling population D99-94) and clone US 4809 (80-4-38) x 'Sweet Charlie' (seedling population D99-95) (Maas et al., 2002). Clone 80-4-38 [F. virginiana clone SG-26 (PI 414129) x F. ×ananassa ('Earliglow')] was selected at Beltsville (JLM) in 1980. Clone SG-89 (Luby no. MS 7-7), collected by M. Stahler in 1986 from Pine County, Minn. $\left(46^{\circ} 00^{\prime} \mathrm{N}, 92^{\circ} 45^{\prime} \mathrm{W}\right)$, was obtained from J. Luby, University of Minnesota, St. Paul. 'Sweet Charlie', earlier determined to be very susceptible to $X$. fragariae (Maas et al., 2000, 2002), was included as the common parent because of its susceptibility to BALD and its resistance to anthracnose (Chandler et al., 1997), caused by Colletotrichum acutatum Simmonds.

BACTERIA. The four $X$. fragariae challenge strains used repre- sented the four genotypic strain groups defined by repetitive element PCR-based assays: ATCC 33239 from Minnesota is the type strain of X. fragariae (American Type Culture Collection, Rockville, Md.); Xf-3 from North Carolina and Xf-6 from California (D. Ritchie, North Carolina State University, Raleigh, N.C.); and Xf1425 from Florida (J. Jones, University of Florida, Bradenton, Fla.). All strains were isolated from, and are pathogenic to, strawberry (Maas et al., 2000, 2002; Milholland et al., 1996; Pooler et al., 1996).

Inoculum was prepared as described in Maas et al. (2000). Briefly, strains were stored in $15 \%$ glycerol gel in culture tubes at $70{ }^{\circ} \mathrm{C}$ until use. Strains were seeded onto solid sucrose peptone agar medium and incubated at $24^{\circ} \mathrm{C}$ for $3 \mathrm{~d}$. Bacteria were washed from culture plates with sterile distilled water, and the suspensions were diluted to a final absorbance of 0.100 at $595 \mathrm{~mm}$, corresponding to $\approx 10^{8}$ colony-forming units $/ \mathrm{mL}$.

EXPERIMENTAL DESIGN. Parental plants and $\approx 120 \mathrm{~F}_{1}$ seedlings from each cross were clonally propagated by stolon-tip plantlet production in the greenhouse. Clonal seedling plants were potted in sterile commercial potting mix and maintained so that at least two young, trifoliolate leaves were available for inoculation. One plant of each parental and seedling genotype, was randomized into each of four blocks. Each trifoliolate leaf receiving inoculum was marked with tape at the time of inoculation, and each leaflet was inoculated in four locations, twice on each side of the midrib. Each plant received 24 inoculations per test and per replication to ensure infection and symptom development with each individual bacterial strain.

INOCULATION. Bacterial culture and plant inoculations were done as described by Maas et al. (2000). Briefly, bacterial suspensions were drawn into a 3-mL syringe, the needle was removed, the syringe aperture placed firmly against the abaxial surface of a leaflet, the syringe plunger carefully depressed until a water-soaked area became visible. Care was taken not to injure the leaflet with pressure from the syringe body. Inoculated plants were placed in individual clear plastic bags for $3 \mathrm{~d}$ in a lighted laboratory at room temperature. Plants were then moved to a mist bench where they were misted for $1 \mathrm{~min}$, three times per hour. After 1 week in the mist bench, plants were moved to benches in a shaded greenhouse at $\approx 24$ ${ }^{\circ} \mathrm{C}$ with a 16-h photoperiod (natural plus supplemental overhead lighting). Plants were watered and fertilized as needed, and insecticides were applied as necessary to control insects and mites.

Evaluation. Disease scoring 2, 3, 4, and 5 weeks after inoculation was done as described by Maas et al. (2000). Inoculation sites were evaluated and rated using the following criteria: $0=$ no reaction, transient water soaking from the inoculation no longer evident; 1 = transient water-soaking evident in the inoculation site; $2=$ slight chlorosis or necrosis in the center of the inoculation site; 3 = water-soaking expanding beyond inoculation site and often bacterial exudates evident; $4=$ necrosis spreading beyond the inoculation site and/or secondary infections evident; $5=$ total necrosis of the inoculation area and leaflet changing color from chlorotic yellow to reddish-brown. Plants of the two resistant clones rated 0. Plants of the susceptible standard, 'Sweet Charlie', always developed severe leaf symptoms and were rated 5 in each test.

Each seedling clone $x$ bacterial strain inoculation was replicated three times in successive experiments using fresh clones for each independent experiment beginning in November 2000 and culminating in May 2001. An average disease score was calculated for each replication based on the disease scores of the four plants representing each genotype. In addition, the average disease scores were converted to qualitative scores ( 0 and 1 were classified resistant, all other scores were classified susceptible). 
Table 1. Broad-sense heritability estimates and $95 \%$ confidence intervals for two octoploid strawberry (Fragaria $\times$ ananassa $\times$ F . virginiana) populations for resistance to four strains of Xanthomonas fragariae, the causal agent of bacterial angular leafspot disease.

\begin{tabular}{lcc}
\hline & \multicolumn{2}{c}{ Strawberry population $^{2}$} \\
\cline { 2 - 3 } Strain & D99-94 & D99-95 \\
\hline Xf-1425 & $0.83<0.87<0.90$ & $0.89<0.92<0.94$ \\
ATCC 33239 & $0.80<0.85<0.89$ & $0.90<0.93<0.94$ \\
Xf-3 & $0.88<0.91<0.93$ & $0.87<0.90<0.92$ \\
Xf-6 & $0.77<0.82<0.86$ & $0.59<0.69<0.76$ \\
Pooled across strains & $0.95<0.96<0.97$ & $0.95<0.96<0.97$
\end{tabular}

${ }^{\mathrm{z} D}$ 99-94 = US 4808 x 'Sweet Charlie'; D99-95 = US 4809 (PI 414129 x 'Earliglow') x 'Sweet Charlie'.

Statistical analyses, heritabiLITy. The three averages were treated as replications in analyses of variance and used to calculate estimates of broad sense heritability. Data were evaluated with the proc glm command of the statistical analysis software SAS 8.2 (SAS Institute Inc., 1999) to create eight separate analyses of variance; one for each combination of the two strawberry populations and four bacterial strains. The estimates of genotypic variance and experimental error derived from each analysis of variance were used to calculate estimates of broad sense heritability using the formula, $\mathrm{H}^{2}$ $=\sigma_{\mathrm{G}}^{2} /\left(\left(\sigma_{\mathrm{E}}^{2} / \mathrm{r}\right)+\sigma_{\mathrm{G}}^{2}\right)$, where $\mathrm{r}$ is the three replications and $\sigma_{\mathrm{G}}^{2}$, genetic variance, is calculated by (mean squares for genotypes - the mean squares for error)/r (Falconer, 1989; Nyquist, 1991; A. Hallauer, Iowa State Univ., personal communication). Bartlett's test for homogeneity of variance was used to determine if an analysis of variance could be conducted using data pooled across all four strains for each strawberry population in order to calculate a single estimate of heritability for each population instead of four separate estimates for each combination of strawberry population and strain. Bartlett's test for homogeneity may be unnecessarily severe (SAS Institute Inc., 1999), so a heritability estimate was calculated from data pooled across strains. A 95\% confidence interval for each estimate of broad sense heritability was calculated using the method of Knapp et al. (1985).

STATISTICAL ANALYSES, CHI-SQUARE TESTS FOR GOODNESS OF FIT TO SEGREGATION RATIOS. The quantitative scores were translated to resistant or susceptible qualitative scores by classifying a genotype as resistant only if all of the replications indicated it was resistant with a score of 0 or 1 . For each strawberry population and pathogen strain combination, the segregation ratios observed were compared with expected segregation ratios of $3 \mathrm{~S}: 1 \mathrm{R}, 7 \mathrm{~S}: 1 \mathrm{R}, 15 \mathrm{~S}: 1 \mathrm{R}$, and 31S:1R, permutations of 1:1 ratios for two, three, four, and five segregating unlinked loci with dominant alleles conferring susceptibility. These ratios were selected because, several researchers have reported segregation ratios of $1: 1$ for molecular markers in octoploid strawberry (Arulsekar et al., 1981; Haymes et al., 1997; LerceteauKöhler et al., 2002; Viruel et al., 2002), indicating a very high level of heterozygosity and supporting, though not demonstrating, disomic segregation. In addition, SSR markers currently under development segregate primarily in a 1:1 ratio in this population (data not presented). Although a 1:1 segregation ratio also is possible for an allooctoploid and an autooctoploid, it seems unlikely that most loci would display 1:1 segregation in either of these two cases. Chisquare values for each strawberry population were summed across strains, and the sums were compared to chi-square values from data pooled across strains for each strawberry population to determine if the data could be combined across strains to test a single segregation ratio for each strawberry population.

\section{Results and Discussion}

Bartlett's test for homogeneity of variance indicated that separate estimates of heritability should be derived for each strawberry population and strain combination. Because Bartlett's test may be unnecessarily conservative, heritability estimates also were derived from data pooled across pathogen strains for each strawberry population. All estimates of broad sense heritability were very high (Table 1), indicating that progress can be made breeding resistant cultivars, determining the genetic control of resistance, and genetically mapping resistance. If the same genes confer resistance to all strains of the pathogen, strain Xf-3 might be a better choice for use in continued genetics research and cultivar development than strain Xf-6, which gave the lowest heritability estimates for both strawberry populations. However, Maas et al. (2000) reported differential pathogenicities of strains ATCC 33239 and Xf-3 to cultivars. Therefore, genetic mapping or screening of selections for a cultivar development program should be conducted with more than one strain.

The high estimates for broad sense heritability support the conversion of the quantitative disease scores to qualitative scores and the classification of genotypes as resistant or susceptible. Analyses of the converted disease scores (as qualitative data)

Table 2. Observed segregation ratios for resistance to each Xanthomonas fragariae strain by strawberry population combination, and the probability of a greater chi-square value for expected segregation ratios of $3 \mathrm{~S}: 1 \mathrm{R}, 7 \mathrm{~S}: 1 \mathrm{R}, 15 \mathrm{~S}: 1 \mathrm{R}$, and $31 \mathrm{~S}: 1 \mathrm{R}$, permutations of $1: 1$ ratios for two, three, four, and five segregating unlinked loci with dominant alleles conferring susceptibility.

\begin{tabular}{|c|c|c|c|c|c|c|c|c|}
\hline \multirow[b]{3}{*}{$\begin{array}{l}\text { Expected } \\
\text { ratio }\end{array}$} & \multicolumn{8}{|c|}{ Strawberry population $^{z}$} \\
\hline & \multicolumn{4}{|c|}{ D99-94 } & \multicolumn{4}{|c|}{ D99-95 } \\
\hline & $\begin{array}{c}3 \mathrm{~S}: 1 \mathrm{R} \\
(88: 30)\end{array}$ & $\begin{array}{c}\text { 7S:1R } \\
(103: 15)\end{array}$ & $\begin{array}{l}15 S: 1 R \\
(111: 7)\end{array}$ & $\begin{array}{l}31 S: 1 R \\
(114: 4)\end{array}$ & $\begin{array}{c}3 \mathrm{~S}: 1 \mathrm{R} \\
(89: 30)\end{array}$ & $\begin{array}{c}7 S: 1 R \\
(104: 15)\end{array}$ & $\begin{array}{c}15 \mathrm{~S}: 1 \mathrm{R} \\
(112: 7)\end{array}$ & $\begin{array}{l}31 \mathrm{~S}: 1 \mathrm{R} \\
(115: 4)\end{array}$ \\
\hline \multicolumn{9}{|l|}{ Strain } \\
\hline \multirow[t]{2}{*}{ Xf-1425 } & 106:12 & 106:12 & 106:12 & 106:12 & 99:20 & 99:20 & 99:20 & 99:20 \\
\hline & 0.000 & 0.407 & 0.051 & 0.000 & 0.035 & 0.167 & 0.000 & 0.000 \\
\hline \multirow{2}{*}{ ATCC 33239} & $109: 9$ & $109: 9$ & $109: 9$ & $109: 9$ & 101:18 & 101:18 & 101:18 & $101: 18$ \\
\hline & 0.000 & 0.097 & 0.436 & 0.011 & 0.011 & 0.407 & 0.000 & 0.000 \\
\hline \multirow[t]{2}{*}{$\mathrm{Xf}-3$} & $109: 9$ & 109:9 & 109:9 & 109:9 & $103: 16$ & $103: 16$ & 103:16 & $103: 16$ \\
\hline & 0.000 & 0.097 & 0.436 & 0.011 & 0.003 & 0.782 & 0.000 & 0.000 \\
\hline \multirow[t]{2}{*}{ Xf-6 } & 106:12 & $106: 12$ & 106:12 & 106:12 & $111: 8$ & $111: 8$ & $111: 8$ & $111: 8$ \\
\hline & 0.000 & 0.407 & 0.051 & 0.000 & 0.000 & 0.053 & 0.697 & 0.042 \\
\hline
\end{tabular}

${ }^{\overline{2} D 99-94}$ = US 4808 x ‘Sweet Charlie’; D99-95 = US 4809 (PI 414129 x ‘Earliglow') x ‘Sweet Charlie’. 
showed that resistance is recessive to susceptibility in both strawberry populations and all four strains tested. Genetically recessive resistance to a bacterial pathogen also has been reported for pepper (Capsicum annuиm L.) genotype ECW 12346 when challenged with $X$. campestris pv. vesicatoria, the cause of bacterial spot disease of pepper (Jones et al., 2002). In both strawberry and pepper, the form of resistance displayed is not a hypersensitive host reaction. In pepper, bacteria infused into host tissues remain viable for a period of time, but neither multiply nor cause disease symptoms. In effect, bacteria become trapped in the host tissue. In pepper, this reaction is conditioned by two recessive genes.

Chi-square goodness of fit tests indicated that three or four unlinked loci could explain the inheritance of resistance in these strawberry populations (Table 2). In population D99-94, the observed strawberry segregation ratios for all four pathogen strains fit either a three gene $(7 \mathrm{~S}: 1 \mathrm{R})$ or four gene $(15 \mathrm{~S}: 1 \mathrm{R})$ model. The same is true in population D99-95 with regard to strain Xf-6, but the segregation ratios for the other three strains fit only the three gene (7S:1R) model. The results of the test for homogeneity of chi-square values indicated that data should not be pooled across strains of the pathogen to determine a single segregation ratio for each strawberry population. Although the observed segregation ratios indicate that resistance may be determined by three to four loci segregating independently, the actual number of genes involved cannot be detected with these analyses, and other possibilities exist. Ambiguity regarding the number of genes controlling resistance is expected due to the level of resolution of the methods used. Incorporation of resistance as quantitative trait loci on a molecular marker map should improve our understanding of the number and effect of genes controlling resistance.

Because resistance is recessive, we assumed that resistant genotypes are homozygous recessive at loci controlling resistance, and that 'Earliglow' and 'Sweet Charlie' have dominant (susceptible) alleles at three or four unlinked loci. Segregation for resistance among $F_{1}$ progeny indicates that some alleles for resistance also are present in 'Earliglow' and 'Sweet Charlie'. If this is true, progeny from self-pollinations also should segregate for resistance at ratios of $63 \mathrm{~S}: 1 \mathrm{R}$ or $255 \mathrm{~S}: 1 \mathrm{R}$, assuming a three gene or four gene model. To reduce the number of susceptible progeny from crosses in a cultivar development program, it may be desirable to utilize resistant genotypes from this study, not only to facilitate introgression, but also to increase genetic diversity of cultivated strawberry. To this end, US 4808 and US 4809 have been released for distribution (Maas et al., 2002). The high estimates for broad sense heritability show that resistant progeny can be selected with confidence, though large populations will be needed to identify enough resistant progeny from which to select for other important traits.

\section{Literature Cited}

Arulsekar, S., R.S. Bringhurst, and V. Voth. 1981. Inheritance of PGI and LAP isozymes in octoploid cultivated strawberries. J. Amer. Soc. Hort. Sci. 106:679-683.

Averre, C.W. and J.G. Driver. 1994. Strawberry (Fragaria Xananassa 'Chandler') angular leaf spot; Xanthomonas fragariae. APS Fungicide and Nematicide Tests 49:71.

Bors, R.H. and J.A. Sullivan. 1997. Introgression of Fragaria species using a streamlined synthetic octoploid system. HortScience 32:548.

Bors, B. and J.A. Sullivan. 1998. Interspecific crossability of nine diploid Fragaria species. HortScience 33:483 (abstr.).

Chandler, C.K., E.E. Albregts, C.M. Howard, and J.K. Brecht. 1997. 'Sweet Charlie' strawberry. HortScience 32:1132-1133.

Cooksey, D.A. 1990. Genetics of bactericide resistance in plant pathogenic bacteria. Annu. Rev. Phytopathol. 28:201-219.
Diekmann, M., E.A. Frison, and T. Putter. 1994. Strawberry angular leaf spot, p. 35-36. In: FAO/IPGRI technical guidelines for the safe movement of strawberry germplasm. Food Agr. Org. U.N., Rome/Intl. Plant Genetics Resour. Inst., Rome.

Epstein, A.H. 1966. Angular leaf spot of strawberry. Plant Dis. Rptr. 50:167.

Falconer, D.S. 1989. Introduction to quantitative genetics. $3^{\text {rd }}$ ed. John Wiley \& Sons, New York.

Haymes, K.M., B. Henken, T.M. Davis, and W.E. Van de Weg. 1997. Identification of RAPD markers linked to a Phytophthorafragariae resistance gene (Rpfl) in the cultivated strawberry. Theor. Appl. Genet. 94:1097-1101.

Hazel, W.J. 1981.Xanthomonas fragariae, cause of strawberry angularleafspot: Its growth, symptomatology, bacteriophages, and control. $\mathrm{PhD}$ thesis. Univ. Md., College Park

Hazel, W.J. and E.L. Civerolo. 1980. Procedures for growth and inoculation of Xanthomonas fragariae, causal organism of angular leaf spot of strawberry. Plant Dis. 64:178-181.

Howard,C.M. 1971. Occurrence of strawberry angularleaf spot,(Xanthomonas fragariae), in Florida. Plant Dis. Rptr. 55:142.

Jones, J.B., G.V. Minsavage, P.D. Roberts, R.R. Johnson, C.S. Kousik, S. Subramanian, and R.E. Stall. 2002. A non-hypersensitive resistance in pepper to the bacterial spot pathogen is associated with two recessive genes. Phytopathology 92:273-277.

Kennedy, B.W. and T.H. King. 1962a. Angular leaf spot of strawberry caused by Xanthomonas fragariae sp. nov. Phytopathology 52:873-875.

Kennedy, B.W. and T.H. King. 1962b. Studies on epidemiology of bacterial angular leafspot on strawberry. Plant Dis. Rptr. 46:360-363.

Knapp, S.J., W.W. Stroup, and W.M. Ross. 1985. Exact confidence intervals for heritability on a progeny mean basis. Crop Sci. 25:192-194.

Lerceteau-Köhler, E., A. Moing, G. Guérin, C. Renaud, V. Parisy, S. Courlit, P. Roudeillac, F.Laigret, B.Denoyes-Rothan. 2002. Genomemapping andQTL analysis in octoploid strawberry (Fragaria Xananassa). Plant, Animal and Microbe Genomes Conf., San Diego, Calif.

Linford, M.B. 1928. Plant diseases in Utah in 1927. Plant Dis. Rptr. Suppl. 59:109.

Luby, J.J., J.F. Hancock, and J.S. Cameron. 1991. Expansion of the strawberry germplasm base in North America, p. 66-75. In: A. Dale and J. Luby (eds.). The strawberry into the 21st century. Timber Press, Portland, Ore.

Maas, J.L. (ed.). 1998. Compendium of strawberry diseases. 2nd ed. APS Press, St. Paul, Minn.

Maas, J.L., C. Gouin-Behe, J.S. Hartung, and S.C. Hokanson. 2000. Sources of resistance for two differentially pathogenic strains of Xanthomonas fragariae in Fragaria genotypes. HortScience 35:128-131.

Maas, J.L., C. Gouin, S.C. Hokanson, and J.S. Hartung. 2002. Strawberry parent clones US 4808 and US 4809 resistant to bacterial angular leafspot disease caused by Xanthomonas fragariae. HortScience 37:716-717.

Maas, J.L., M.R. Pooler, and G.J. Galletta. 1995. Bacterial angular leafspot disease of strawberry: Present status and prospects for control. Adv. Strawberry Res. 14:18-24.

Milholland, R.D., D.F. Ritchie, M.E. Daykin, and W.A. Gutierrez. 1996. Multiplication and translocation of Xanthomonas fragariae in strawberry. Adv. Strawberry Res. 15:13-17.

Nyquist, W.E. 1991. Estimation of heritability and prediction of selection response in plant populations. Crit. Rev. Plant Sci. 10:235-322.

Pooler, M.R.,D.F. Ritchie, and J.S. Hartung. 1996. Genetic relationships among strains of Xanthomonas fragariae based on random amplified polymorphic DNA PCR, repetitive extragenic palindromic PCR, and enterobacterial repetitive intergenic consensus PCR data and generation of multiplexed PCR primersuseful for theidentification of this pathogen. Appl.Environ. Microbiol. 62:3121-3127.

Roberts, P.D., R.D. Berger, J.B. Jones, C.K. Chandler, and R.E. Stall. 1997. Disease progress, yield loss, and control of Xanthomonas fragariae on strawberry plants. Plant Dis. 81:917-921.

SAS Institute Inc. 1999. SAS Online Doc. version 8. SAS Inst. Inc., Cary, N.C. Sjulin, T.M. and A. Dale. 1987. Genetic diversity of North American strawberry cultivars. J. Amer. Soc. Hort. Sci. 112:375-385.

Viruel, M.A., D. Sánchez, P. Arús. 2002. An SSR and RFLP linkage map for the octoploid strawberry (Fragaria $\times$ ananassa) Plant, Animal and Microbe Genomes Conf., San Diego, Calif. 